\title{
Jeux sans frontières
}

\author{
Sheldon Krimsky
}

The Biotechnology Revolution: An International Perspective. By Alan M. Russell. Wheatsheaf, Brighton, UK/St Martin's Press, New York: 1988. Pp. 266. £35, \$45.

WHEN gene splicing emerged as a research tool in molecular genetics, world-wide concern over safety was encapsulated in the apothegm 'microbes do not respect national boundaries'. This phrase carried a meaning to all participants in the complex and sometimes frustrating debates over the governance of recombinant DNA (rDNA) research. Those who advocated de minimis voluntary guidelines pointed to the absurdity of some countries imposing containment standards that exceeded an accepted norm. They knew that no country was willing, unilaterally, to forego a strong start in the race to develop biotechnology. The metaphor of organisms with international passports was used to promote regulatory harmonization - a convergence towards uniform minimal safety standards.

Advocates for stringent controls, including those who supported the establishment of several high-containment laboratories in each nation, also exploited the symbol of microbes and boundaries in advancing their case. One such boundary was the putative evolutionary separation between eukaryotic and prokaryotic organisms, so-called species barriers which rDNA technology so easily breached. Species

barriers were cited to call attention to the broad evolutionary consequences of the new technology in contrast to narrowly posed risk assessment. The regulatory maximalists also acknowledged the irrelevancy of national borders to peregrine microbes. However, from this insight they concluded that control of this technology should be given over to a world congress or international convention. Both biological and political boundaries played an important symbolic role in the carly debates over gene-splicing.

All this is history now. rDNA technology is celebrating its fifteenth anniversary. The science is no longer obscure and practical applications are abundant. There are high-school kits for gene-splicing experiments. Gene sequencing has even been introduced into the courts as a method for identifying criminal suspects. Industralization of biotechnology has produced new symbols such as global rDNA markets, patents on life and university-industry partnerships. The international aspects of biotechnology are more complex now than they were in 1975 when scientists throughout the world gathered at Asilomar "to review the progress, opportunities, potential dangers and possible remedies

dependency on the industrialized nations through the latter's appropriation of germ plasm and through socio-economic dislocation resulting from substitution of biosynthetic products for natural ones. The development of replacements for export crops (vanilla from Madagascar, codeine from Turkey, cocoa butter from the Ivory Coast, gum arabic from Nigeria) portends a global agricultural restructuring that some believe is now well underway. Biotechnology is rapidly becoming part of a world economic order.

Alan M. Russell, a lecturer in international relations at North Staffordshire Polytechnic, has produced a book that provides an international perspective on one of several important stages in the development of biotechnology. It discusses the efforts by nations and international scientific societies to address the safety of rDNA laboratory experiments. The first half of it recapitulates the history of American and British responses to the concerns expressed in the Berg letter, published in Science and Nature in 1974, and at the Asilomar conference. The author's historical analysis draws exclusively on the existing literature and heavily on the DNA archives at the Massachusetts Institute of Technology. The book adds little to reconceptualizing the historical record, nor does it contribute a new body of critical information. Although generally well researched, the author's account of the development of rDNA guidelines in Britain has a glaring omission in failing to acknowledge The Politics of Uncertainty, by D. Bennett, P. Glasner and D.

associated with the construction, and introduction of new recombinant DNA molecules into living cells". Concern about hazards has shifted from the laboratory to the open environment. Today, appeals for regulatory harmonization come most prominently from the multinational companies which proclaim that 'DNA markets have no national boundaries'.

Internationalization of biotechnology means something different to Third World countries, where it raises both hopes and anxieties. The hopes are based on a technology with low capital costs, that is easily transferred, that could be respectful of ecological diversity and therefore efficiently make use of indigenous crops, and that may offer inexpensive vaccines for mass immunization. But the anxieties run deep and for good reasons. Developing countries may face a second generation of
Travis, a leading scholarly treatment of the subject published in 1986.

In the second half of the book, the author's strengths in international relations, organizational theory and descriptive network analysis are more evident. Russell examines the response by influential international scientific groups such as the European Molecular Biology Organization, the International Council of Scientific Unions and the European Science Foundation to the potential hazards of rDNA research. These bodies served as counter-influences to the tendencies of individual states to set up radically different standards for rDNA research. They set limits on the uncertainty of the risks, consolidated information, sought consensus positions and served as communication channels to strategic policy circles. These organizations operated according to a design: to advance the cause of inter- 
national science by counteracting the balkanization of interests.

After the British and American guidelines were published and public debate began, scientists closed ranks with extraordinary speed. In the scientific community there was but a small chorus of dissident voices, primarily in the United States; James Watson referred to these people as "shits, kooks, and incompetents". Russell's conclusion about the consensus within the scientific community holds true for both the national and international groups: "Although it can be questioned whether scientists avoid the pressures of nationalism, especially in large-scale prestige science, it is fair to say that for genetic manipulators the common international fear of excessive regulation enhanced their unity of purpose" (p.209). His analysis is consistent with that of other historians who have delved into the archival materials and read through mountains of reports: (1) the science of risk assessment was politicized; (2) scientific groups at the national and international level limited the discussion of biotechnology to laboratory risks, excluding the social and ethical implications; (3) policy options among scientists were narrowed by self-interest.

The strongest features of this book are its discussions of international scientific networks and the role they played in the early debates over rDNA. However, it is primarily a discussion of events (not the people who shaped them) and formal relations among transnational institutions. Russell describes the patterns of interaction among scientists as "multilevel overlapping systems". His use of network analysis and organizational theory, unfortunately, does not deepen our understanding of the historical events. There is little substantive analysis of the effect that second-order (international) organizational structures had on the way that firstorder (national) structures handled risks.

We learn from this study that the systems designed to promote scientific exchange and cooperation were highly successful in structuring the international debate over biotechnology. Moreover, the same scientific groups that were so effective in damping the regulatory oscillations for rDNA research have been noticeably silent on associated ethical dilemmas. We have heard little from them on such issues as American scientists using Third World nations as testing grounds for new vaccines, growing secrecy within the biological research community and the rise in world-wide military interest in biological weapons.

Sheldon Krimsky is an Associate Professor in the Department of Urhan \& Environmental Policy, Tufts University, 97 Talbot Avernue, Medford. Massachusetts 02155, USA, and author of Genetic Alchemy: The Social History of the Recombinant DNA Controversy (MIT Press, 1982).

\section{The good and the great}

\section{Stuart Sutherland}

A Passion for Science. By Lewis Wolpert and Alison Richards. Oxford University Press: 1988. Pp.206. £15. To be published in the United States in August, price $\$ 21.95$.

Scientists lead an enviable life. They richly deserve to do so, for they are an exceedingly pleasant lot - or so it would appear from the remarks of the 13 interviewed by Lewis Wolpert for the BBC.

Their work is fun, a word that appears again and again. Indeed it is so much fun that some of them feel a little guilty about their self-indulgence. Few of them mention the weary weeks or months spent unsuccessfully trying to solve a problem or to make an experiment work, let alone the misery of discovering that someone else has got there first. Oddly, the issue of priority is hardly raised, though depending on which way it goes it probably causes more joy and heartbreak than anything else in science.

With the exception of Stephen Gould, they lack any trace of conceit: one cannot help wondering how such bashful virgins came to achieve such eminence. When awarded Nobel prizes, their immediate reaction is to think the Nobel Committee has written to the wrong chap. They modestly point out that chance played an important role in their most important discoveries. John Maynard Smith was prompted to invent the concept of an evolutionarily stable strategy and to carry out the mathematical analysis that underpinned it by reading an unpublishable paper that he happened to referce. And according to his own account, Francis Crick entered biology because he was told to do so by a physicist he knew during the war, and he met Jim Watson by accident.

The moral virtues displayed by Wolpert's scientists are remarkable. They do not steal ideas from their colleagues, though they may steal their wives from time to time. They never ever cheat in science, though we are not told whether they defraud the customs or the Inland Revenue. Nor do they pinch ideas without acknowledgement, even if they are sometimes tempted to pinch their au pairs' bottoms. And if they have ever had cantankerous arguments with fellow scientists, they do not mention them. It is all very bland. True, Sydney Brenner raises a smile when he recounts how he advised a student to stop Xeroxing articles. When he told him to "neurox" them instead, he had to explain what he meant. Neuroxing is "a very casy and cheap process. You hold the page in front of your eyes and you let it go through there into the brain. It's better than Xeroxing".

Although it may be hard to believe the scientists' self-portraits, their accounts of their work are always clear and there is the occasional nugget of information. For example, Michael Berry explains that the inevitable uncertainty about the position of an electron at the known limit of the Universe will cause an error of up to $90^{\circ}$ in the predicted direction of a gas molecule on Earth after it has collided only 50 times with other molecules, a process that takes a fraction of a microsecond.

One longs for more of this kind of thing rather than being repeatedly told that science is fun. Indeed the book's worst fault is that it shies away from proper explanations. There is a clear account by Anthony Epstein of how the Epstein-Barr

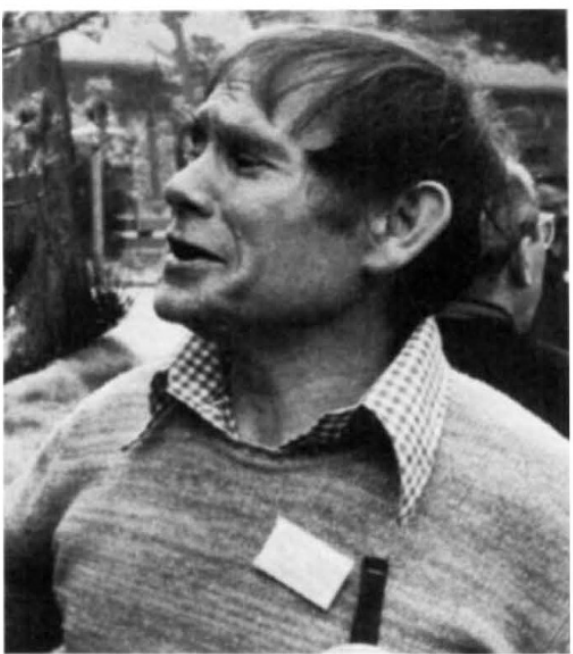

Sydney Brenner - in praise of the neurox.

virus was discovered: the reader is repeatedly told how important the discovery was, but he never learns why. It is true that the BBC usually aims to present material that will not stretch the intellect of a fiveyear-old, but the lack of more detailed expositions of what was found out and why it was important is frustrating.

It may be that anything more difficult would have driven listeners away. Wolpert himself argues in his introduction that for two reasons science is little respected in Britain and hence is understood by few. First, the romantic movement, at least in the shape of Coleridge followed by D.H. Lawrence, took an anti-reductionist stance. But engineering was widely admired in Victorian times, even by some poets like Tennyson and subsequently Kipling. Moreover, in the 1930s and 1940s names like Jeans and Eddington were household words, but if in a pub quiz today there was a question asking the name of any living astrophysicist, the quiz devotees would probably arise as one and drench the quiz master with Guinness for setting an unfair question. Wolpert's second argument also seems weak. He writes "the scientific mode of thought is neither natural nor comfortable". But it is 